\title{
Identity and Agency Development in a CLIL-based Teacher Education Program
}

\author{
Josephine Moate \& Maria Ruohotie-Lyhty, University of Jyväskylä \\ josephine.m.moate@jyu.fi; maria.ruohotie-lyhty@jyu.fi
}

\begin{abstract}
A consensus exists in applied linguistics that agency and identity are key concepts in understanding teacher development. Although a large body of research has focused on studying language teacher and learner identity and agency separately, less attention has been paid to the relationship of these concepts in individual development. In this contribution, we use an ecological perspective to explore and illustrate the interplay between and development of agency and identity. The participants in the study were primary school teacher students specializing in foreign language pedagogy for younger learners and studying in a CLIL-based teacher education program. The qualitative data were collected through reflective essays focusing on the Finnish student teachers' past, present and future relationships with the English language during different phases of their bachelor's studies.
\end{abstract}

Keywords: CLIL teacher education, ecological perspective, identity, agency 
(1) During this year I have understood better that learning English is so much more than just learning things by heart and that thought has also shaped my idea of what kind of English teacher I would want to be in the future. (Elisabeth $2^{\text {nd }}$ essay)

Our particular interest in this contribution is to better understand the way in which agency and identity inform the development of future primary school teachers studying in a CLIL-based teacher education program. In recent years, pre-service language teachers' identity and agency have been studied from varied perspectives. The studies focusing on identity have provided a view on the ways in which student teachers envision their future work and in which ways the particular social contexts resource this process (Barcelos, 2016; Barkhuizen, 2009; Kalaja, 2016; KayiAydar, 2015; Trent, 2013). These studies have also provided a view into the active process of identifying and dis-identifying with other teachers and teaching practices that is necessary for language teacher development (Kalaja, 2016; Trent, 2013). Studies focusing on pre-service language teacher agency have also highlighted the active process of meaning making necessary for teacher development (Kayi-Aydar, 2015) and shed light on the ways in which different social conditions interrelate with pre-service teacher agency.

Although identity and agency research have become increasingly present in pre-service language teacher research, less attention has been given to these concepts in Content and Language Integrated Learning (CLIL) education. Within the teacher education program in this study, CLIL was adopted as the approach in order to "complement and enhance traditional foreign language education and to open doors to innovative classroom pedagogies also in content subjects" (Dalton-Puffer et al., 2014 , p. 214). Using an additional language to learn or teach content matter introduces a number of significant challenges. As CLIL research suggests the change in language(s) used requires greater awareness of the role and presence of language in education as a central mediator of learning and teaching (Moate, 2011). As teachers and learners work through a different language, teachers have to find, modify and develop new materials and pedagogical approaches to meet the needs of learners (e.g., Coyle, 2008;
Meyer, 2010). Moreover, CLIL research suggests that relational realignments are often needed to overcome the challenges of CLIL for teachers and learners. These relational realignments can be in the classroom, for example as teachers find new ways of expressing themselves through a foreign language and understanding the experiences of learners, as well as in the educational community as teachers work together to develop CLIL-based education (e.g., Moate, 2014; Pappa et al., 2017a, 2017b). Whilst some changes introduced by CLIL approaches can be anticipated by CLIL stakeholders, some changes can be more subtle and less easy to identify, but arguably any significant change challenges the members of a community to realign and reconsider who they are within the community and how they can act (Sylvén, 2013). These challenges, better described as "disjunctures", as what was and what now is no longer align, can be valuable opportunities for reconsidering the agency and identity development of teachers (Moate, 2013). This contribution focuses in particular on the way in which the integration of content and language learning can create disjunctures within teacher education and the ways in which student teachers' responses to disjunctures inform their development as language learners and future teachers. We begin this contribution by providing a brief theoretical account of agency and identity before introducing the ecological perspective used in this study and the study itself.

As theoretical concepts, agency and identity both incorporate understandings of self or selfhood. As understandings of self have varied over the centuries, so the concepts of agency and identity have similarly developed from essentialist to more complex definitions (Vitanova et al., 2014) with complex conceptual tools being drawn from a wide variety of disciplinary perspectives. Over time, agency and identity have increasingly been described in similar terms. Both agency and identity are described as having moments of greater and lesser stability, as intrinsically related to the wider social context (e.g., Duff, 2012; van Lier, 2008), as extremely personal, deeply felt, and under constant negotiation (e.g., Norton, 2006; Ruohotie-Lyhty, 2013). Arguably these two concepts have become increasingly "entangled" (Vitanova et al., 2014, p. 2). Although these two concepts can be usefully differentiated through the focus of identity on the "who" of the individual(s) and the focus of agency on the "how" of individual(s); how these concepts relate to or contribute to 
one another remains an open question. The following sections provide brief overviews of agency and identity within the field of applied linguistics before introducing the specific context for our research and the way in which we have attempted to better understand the relationship between agency and identity from an ecological perspective.

\section{Agency and Applied Linguistics}

Agency has been brought into the field of applied linguistics through a number of different "theoretical" doorways including social theory, sociocognitive theory, performativity, sociocultural theory as well as complex dynamic systems theory (Larsen-Freeman, 2019). Although definitions in applied linguistics often refer to the established understanding of agency as the capacity to rationally and intentionally act in the world (Giddens, 1984). The way in which agency has been accepted as a "natural" capacity of an individual responding to situational opportunities and constraints, however, has been criticized as an oversimplification. Miller (2016), for example, suggests an agent should be recognized as a nexus in which historical, political and discursive conditions come together, primarily through discourse, to construe agency. This stance challenges the notion that individuals have power to act as they wish and complements research that has sought to differentiate between an individual's sense of agency and the exercise of agency (e.g., Mercer, 2012).

The formative relationship between an individual and their environment, however, is a central consideration in theorizations of agency particularly within the field of language education and language teacher development (Feryok, 2012; Larsen-Freeman, 2019). Working from a sociocultural perspective, Pavlenko and Lantolf (2000) have drawn on temporality to examine agency as an act that draws on the past to realize the present. Other research drawing on sociocultural theorizations emphasize agency as a mediated phenomenon negotiated and co-constructed between an individual and the environment (e.g., Lantolf \& Thorne, 2006) as well as acknowledging the way in which surrounding relationships and conditions enable and constrain the enactment of agency (Aro, 2016). These approaches, however, have tended to underplay the mutually constitutive relationship between individuals and the environment (Feryok, 2012).
Complex dynamic systems theory (CDST), together with an ecological perspective, seeks to avoid dichotomizing the parts of a system by recognizing the whole as a system that is neither reducible nor separable from the ever-changing space-time in which it is situated. Moreover, a CDST perspective suggests that the complex interaction of the parts cannot be predicted as it is not preformed through the conditions, rather interaction should be recognized as bi-directional, synchronous co-adaptation. Drawing on CDST, Larsen-Freeman (2019) suggests that, "What propels the change in humans is the reflexivity of which they are capable" (p. 64) and that the necessary "level of granularity" to understand the "uniqueness of learning trajectories" is "the individual interacting with the environment" (ibid., p. 73). From this perspective, the agency of a learner is essential for optimizing learning conditions, yet any pattern that forms within the system is only temporary and liable to change suggesting that any system is inherently instable (Larsen-Freeman, 2007). An ecological perspective similarly brings to the fore the mutual dependence between individual and environment to understand the uniqueness of each ecology for learning (van Lier, 2010). A significant difference, however, between CDST and ecological perspectives is the potential stability of a system as an ecological perspective allows for the presence of patterns and the formation of habits (van Lier, 2010).

To suggest that agency can be habitual appears to go against the grain of much contemporary research in applied linguistics that appreciates the intentionality or autonomy of agency. Habits can be understood as the oil that keeps the cogs of daily life smoothly running (Kraftl, 2013) and as patterns of behavior that are initially chosen in response to a particular situation that become generalized over time (Owens, 2017). This does not absolve individuals from the responsibility of forming good habits nor does it suggest that once established habits cannot be reformed (Levine, 2015). Recognizing the habitual tendency of agency, however, may help explain why encountering a new environment can be uncomfortable as habitual ways of being and doing no longer align with the environment. Moreover, we suggest that recognizing agency as at least in part habit formation introduces stability into the relationship between the individual and environment. In this contribution, we perceive agency in accordance with these previously presented perspectives as co-constructed 
between an individual and the environment and as subjectively reflexive and experienced. Before turning to the empirical implications of these theorizations, however, we now turn to conceptualizations of identity in the field of applied linguistics.

\section{Identity and Applied Linguistics}

The theoretical doorways through which agency entered applied linguistics research are similar to those through which identity entered the field including sociocultural theory and poststructuralism, as well as critical and feminist theorizations, narrative approaches, phenomenology and hermeneutics (Duff, 2012). Whereas agency is often dichotomized between volitional action and negotiated interaction, identity has been dichotomized between identity assigned based on group membership or cultural heritage and identity negotiated in relation to particular environments (Duff, 2012). As with agency, these two definitions indicate the way in which identity was initially conceptualized as an individual phenomenon before the inevitable presence of the environment was recognized. That an individual, however, can have multiple identities in relation to multiple environments contrasts with conceptualizations of agency, in that agency is understood to take different forms (relational agency, identity agency, pedagogical agency). Theorizations of identity, however, suggest an individual can have multiple (e.g., Block, 2007; Duff, 2012), as well as transportable identities (Dörnyei, 2009), albeit held together within the physical, sociohistorical experience of a person (Sade, 2009). Empirical studies also demonstrate the complex interplay these identities have with different contexts in student teacher development (e.g., Barcelos, 2016; Barkhuizen, 2009; Kalaja, 2016; Kayi-Aydar, 2015; Trent, 2013).

In applied linguistics, identity has been defined as "the way a person understands his or her relationship to the world, how that relationship is structured across time and space, and how the person understands possibilities for the future" (Norton, 2013 cited in Norton, 2016, p. 476). This definition emphasizes the relational nature of identity and sense of self as well as the longitudinal aspect of identity that extends from the past into the future. Moreover, identity has been recognized as personal longing - "a desire for recognition, affiliation, security, and safety" these desires cannot be automatically satisfied, however, as they "are all dependent on how material resources are distributed in society" (Kalaja et al., 2016, p. 18). This perspective foregrounds the material, socio-political and emotional aspects of identity and the complex interrelations that inform identity development. With the introduction of identity to applied linguistics research, a shift has taken place from observing what language learners do, to how they are placed in and experience themselves in the world (Duff, 2012) and the development of hybrid identities (Kramsch, 2009).

In recent years, CDST has also been used in identity research to better understand identity development within a dynamic system that allows for a multiplicity of self/selves to develop through multiple interactions and environments. This approach appears to answer the paradox as to why socially formed individuals can be considered unique as Sade (2009) illustrates with her study on complexity and identity reconstruction. Sade uses the Bakhtinian notion of polyphony to acknowledge the presence of many voices within a particular context that an individual can appropriate, modify and intone with their own meaning. As different voices meet and meld, social histories become part of individual experiences and expressions. This meeting between voices enables continuity of what has been, as well as variation (Bakhtin, 1981); complexity theorists might describe this merging as emergence (Larsen-Freeman, 2019) as something new is created. Sade (2009) suggests that as an individual interacts with different voices in different localities creating a unique, fractalized, rather than fragmented, identity: “... the relations established among the social identities give a sense of "wholeness" to the self" (Sade, 2009, p. 152). As with the ecological perspective, these moments of encounter can be described as "risky moments" as "each decision made of this kind involves risk and a rupture with past established habits" (Giddens 2002, p. 72 cited in Sade, 2009). Rupturing habits can destabilize the present as links with the past break and familiar resources are no longer available or appropriate (Vanderstraeten \& Biesta, 2006). It is "risky moments", however, that create fundamental affordances for development within an ecological system, as well as from a complexity theory perspective, as it is risky moments that co-constitute the system, or the overall ecology as we suggest below. 


\section{Conceptualizing the Ecological Perspective on the Individual - Environment Relationship}

Conceptualizing the individual - environment relationship is an enduring endeavor that has been revised throughout history with significant implications for the lives of individuals, communities and societies (Bauman, 2000), as well as for human and scientific development (Bruner, 2012), and is reflected in the various reformulations of agency and identity as outlined above. Each perspective, nevertheless, assumes a relationship between an individual and the environment as even the most individual-based theory requires an environment to be able to distinguish the existence of individuals; a sense of self cannot exist without the sense of another (Bakhtin, 1993). The more important question, however, is the quality and purpose of the relationship between an individual and the environment.

An ecological perspective recognizes the relationship between individuals and the environment as mutuallydependent with both parties fundamentally contributing to the continual formation of each other (Biesta \& Burbules, 2003; van Lier, 2010). From this perspective, the individual and environment remain distinct from one another, but there is no discrete or even possible separation between the two (Rayner, 2011). The ecology, therefore, is the relationship shared by and encompassing the individual and the environment; the ecology is not the individual plus the environment, but the individual and environment "in relation". The responsivity of both individuals and the environment is critical to the form and formation of the ecology: as individuals sense change in their environment so they have to respond in order to realign themselves or the relationship, and as the environment recognizes change in individuals, so the environment reforms or is reformed. This relationship should not be understood as a conventional stimulus-response exchange or cause-effect, but rather a sensitive awareness of self and other that seeks to keep "insync" by anticipating developments and intelligently responding (Holquist, 1983). In this relationship, separation between the individual and environment is not an option as it is only by being in relation that they are sustained. As an ecological perspective provides the theoretical foundation for this contribution, this means that as a starting point we recognize the fundamental relationship between the individual student teachers and the environment of the teacher education program.

\section{METHODOLOGY}

\section{Context and Participants for this Research}

The aim of this study is to examine the critical interplay between agency and identity in student teacher development within the specific context of CLIL education. The data for this study come from the first three-years of a Bachelor's program (leading to a Master's program) for primary school teachers called JULIET (Jyväskylä University Language Innovation and Educational Theory). As part of this program, the students complete minor studies in English and specialize in foreign language pedagogy and content and language integrated learning (CLIL). A key characteristic of this program for these students was the integration of educational and foreign language studies. In this case, the foreign language was English for these Finnish-speaking participants. The aim of this approach was to offer the students a genuine experience of CLIL pedagogy. As a CLIL-based teacher education program, lectures for the entire year group were in Finnish, but our participants studied education in the JULIET "home group" through English with additional JULIET language courses providing support for the educational studies. In the JULIET courses, the focus is on participating through English and being involved in a variety of different activities instead of explicit study of the language. Moate and Ruohotie-Lyhty (2014) provides a more detailed overview of JULIET as a model of teacher education.

The participants of the study are one cohort of students in the JULIET homegroup. Two of the students were male and ten female. Whereas 11 of the participants were about 20 years of age when entering the program, one student had had a career in another field before primary school teacher studies and was somewhat older than the other students. Each participant had studied English as their first foreign language at school starting from grade 3 . In addition, one of the students had been in an English mediated kindergarten and a couple of the students had had an exchange experience in an English-speaking country before entering teacher education. JULIET as a CLIL based education model was, however, a new environment for the student teachers. 


\section{Data and Data Analysis}

The dataset that we use here comes from the essays written by the student teachers at the start of their studies, and reflective essays written at the end of the first and second years of study (see Table 1 for a summary of the data). In the essays, the students were asked to reflect on their relationship with the English language in light of their previous experiences, current experiences in the program and as future teachers. The three essays were entitled "English and me", "English, JULIET and me" and "My relationship with English as a global language".

Whilst we have used a data-driven analytical procedure in our former studies with this data (For more information on these earlier studies see Moate \& Ruohotie-Lyhty, 2014, 2020; Ruohotie-Lyhty \& Moate, 2015, 2016), this contribution adopts a theory-driven approach to data analysis (cf. also Miller, 2016). We began with a review of the different theorizations of agency and identity and then identified four theory driven assumptions to examine the development of student teachers within a CLIL-based environment. In other words, we did not use a ready-made theoretical model, but constructed a theoretically informed hypothesis of the nature of the process. The four underlying assumptions are: (1) A CLIL-based teacher education model posits a challenge for the participants' habitual agency (Giddens, 2002), (2) the participants' need to reflexively respond to this disjuncture (Larsen-Freeman, 2019; Rayner, 2011), (3) emerging ecologies will inform the development of agency (van Lier, 2010), and (4) the new ecologies will resource identity development (Sade, 2009), as the ongoing negotiation within the individualenvironment relationship creates new affordances. In the analysis, we initially read through the essays to ascertain whether the assumptions resonated with the participants' texts. The presence of the different themes is indicated in Table 1. The next step was to examine how these theoretical assumptions played out in the level of our data by identifying key moments shared by the students (Sullivan, 2012). Key moments often comprised meaningful experiences shared by the participants when they were trying to make sense of the new environment, their role and expectations, as well as the negotiation of new relationships. As in our previous research, we paid close attention to the temporal and relational conditions of these experiences and the way in which experiences changed and developed over time. In this paper, each of the theoretical assumptions is introduced as a theme of a sub-chapter.

Table 1. Participants, Data and Themes

\begin{tabular}{|c|c|c|c|c|c|}
\hline $\begin{array}{l}\text { Participant } \\
\text { pseudonyms }\end{array}$ & Data (essays) & $\begin{array}{l}\text { The challenge of } \\
\text { a CLIL-based } \\
\text { learning } \\
\text { environment }\end{array}$ & $\begin{array}{l}\text { Reflecting on } \\
\text { disjunctures }\end{array}$ & $\begin{array}{l}\text { Forming new } \\
\text { ecologies }\end{array}$ & $\begin{array}{l}\text { Resources for } \\
\text { future language } \\
\text { teacher identities }\end{array}$ \\
\hline Hannah & 1,2 & $\mathrm{x}$ & $x$ & $x$ & \\
\hline Ella & 1,2 & $x$ & $\mathrm{x}$ & $x$ & \\
\hline Jane & $1,2,3$ & $x$ & $x$ & $x$ & \\
\hline Julia & $1,2,3$ & $x$ & $x$ & & $x$ \\
\hline Marie & $1,2,3$ & $\mathrm{x}$ & $x$ & $x$ & $x$ \\
\hline Markus & $1,2,3$ & & $x$ & $x$ & $x$ \\
\hline Elisabeth & $1,2,3$ & & $x$ & $x$ & $x$ \\
\hline Annie & $1,2,3$ & $\mathrm{x}$ & $\mathrm{x}$ & $x$ & $x$ \\
\hline Paula & $1,2,3$ & $x$ & & $x$ & $x$ \\
\hline Niklas & $1,2,3$ & $\mathrm{x}$ & $\mathrm{x}$ & $x$ & \\
\hline Laura & $1,2,3$ & $x$ & $x$ & $\mathrm{x}$ & \\
\hline Mia & 1,2 & $x$ & $x$ & $x$ & $x$ \\
\hline
\end{tabular}




\section{CLIL-BASED EDUCATION INFORMING ECOLOGIES INFORMING ECOLOGIES FOR TEACHER AGENCY AND IDENTITY DEVELOPMENT}

This section provides examples of the ways in which this CLIL-based teacher education context informed the identity development of the student teachers. We illustrate the ways in which the disjunctures of a new environment and a new language challenge the student teachers' habitual agency and potentially resource their identity development. The development process is demonstrated through four themes typical of the student experiential pathway: "The challenge of a CLIL-based learning environment, Reflecting on disjunctures, Forming new ecologies, and Resources for future language teacher identities". Table 1 provides an overview of the presence of themes in the participants' essays. The average length of the first essay was 2015 words and for the second and third essays 1294 and 1216 words respectively.

\section{The Challenge of a CLIL-based Learning Environment}

The beginning of this CLIL-based teacher education was quite a difficult experience for many of the students in the program. They entered the English-mediated teacher education program with their previously formed language identities that emphasized native-likeness, fluency and grammatical correctness. Being individuals who were ready to invest in their language proficiency, they considered the program to be an opportunity to improve their skills. At the same time, however, the entrance to the program seemed to generate a sense of inadequacy and the fear of failure rather than a sense of success or achievement. Established ways of being agentive language learners appeared to heavily affect the student teachers' experiences of the group. The students exercised their former, or habitual, ways of being agentive and compared themselves to other students, often with a negative conclusion as "Hannah" states:

(2) I realized quickly my limitations when our studies began. Suddenly, I felt myself very poor in speaking and delivering other ways in English; all the others were so good and experienced. I also became aware of their strengths and my own weaknesses a lot more. I started to compare myself to others and it was clear that I was one of the weakest in the group. This was new to me: to be one of the lousy ones. (Hannah, $2^{\text {nd }}$ essay)

For Hannah, learning a language was connected with the idea of competing with others and trying to be the best. Although this was not emphasized in this teacher program, many of the students entered the program with these beliefs and tried to act accordingly. The challenge of performing through English even made some of the students doubt whether they wanted to continue to be part of the program, as "Jane" says:

(3) There has been moments when I have doubted if I have what it takes. Many thoughts of quitting JULIET have been in my head because I have felt that I am not good enough and the development hasn't been satisfied. The empty page on my computer screen has been sometimes so high obstacle and the power in me has felt so tiny when I had to write in English. Also the doubt if I will ever be able to work with children only in English since it is still so hard for me to speak English fluently. (Jane, $2^{\text {nd }}$ essay)

Being in an English-mediated program also seemed to activate some of the students' previous ideas of language. In addition to a competitive stance, many students seemed to indicate how initially the new environment challenged their beliefs about how language should be learnt. Their previous experiences of language learning typically involved the explicit study of language structures and vocabulary. This way of understanding language learning collided with the work culture of the CLIL-based program. Instead of offering courses on grammar and vocabulary, the English language was used as a way of communicating pedagogical content, a form of participation and a tool for building understanding. The lack of explicit English grammar and vocabulary teaching made the students question the value of the activities for their language learning as Hannah says:

(4) I have had this feeling that I have learned nothing new during this year. I have nothing concrete to reply if somebody asks what have you learned in the university. (Hannah, $2^{\text {nd }}$ essay)

For Hannah, the university studies did not resemble her previous experience of learning and therefore she had difficulties to recognize that learning was still taking place. 
In general, entering the new CLIL environment challenged many established ways of being an agentive learner. Initially the students struggled to make sense of the environment, experiencing inadequacy as their assumed ways of being and doing did not align with the ways of being and doing promoted in the program. Whilst the experience of this disjuncture initially prompted the students to question their own adequacy, over time they began to reflect on the disjuncture between their expectations and the environment, and to begin to make sense of what was happening. Through this interplay of experiences and expectations the evolving ecology of the CLIL-based program began to take shape.

\section{Reflecting on Disjunctures}

In the course of the first year of their teacher education studies, the students started to notice that their original ideas of language learning environments had emphasized grammatical correctness, fluency and a competitive stance which did not apply to or align with their new learning environment. In their essays, this sense of disjuncture was often raised by students as in the examples from "Elisabeth" and "Paula":

(5) At school I was also used to that I would usually be corrected by my teacher, but in JULIET not so much effort has been put on making our use of language grammatically correct. (Elisabeth, $2^{\text {nd }}$ essay)

(6) We noticed we can be ourselves in the class with our strengths and flaws. There would not be any laughs if a mistake should occur. Everyone was supporting each other, sharing knowledge, and hoping everyone to succeed. (Paula, $2^{\text {nd }}$ essay)

The disjuncture they experienced seemed to sensitize the students and to encourage them to look around more attentively to find other possible ways of participating that were available in their environment. Hannah explains how she came to question her ways of understanding the JULIET group and the expectations of language proficiency.

(7) I made up this image that all the JULIETs are excellent in English especially the "older" students. When we had a meeting with the third-year JULIET's, I realized that not all of them had a great pronunciation or vocabulary and it was okay. We are all accepted just the way we are. Realizing this was a huge relief to me. (Hannah, $2^{\text {nd }}$ essay)

The struggles the participants faced when trying to make sense of their agency as English speakers in the program generated the need to reconsider their senses of themselves, their self-worth and their ways of participation. The reflective texts of the students narrated a sense of self formed in relation to a sense of (in)competence and high expectation that qualified the students' language learner identities, illustrated in these examples from Hannah and "Marie":

(8) I consider myself to have good language skills... Still, I do not feel myself good enough. Why I am trying to achieve something that is impossible? (Hannah, $3^{\text {rd }}$ essay)

(9) I found myself thinking, really thinking, that line. Was I good at English? Why do I feel my selfesteem of English has become lower? Would it help to just accept my role, to take a deep breath and not to push myself too hard? How could I help myself to build up more confidence in my own abilities with English? (Marie, $2^{\text {nd }}$ essay)

For these students, the disjunctures between their former language learner identities and their experiences in the bilingual program prompted and mediated the reconsideration of their previous identities and ways of being agentive as well as greater sensitivity to the conditions of the new environment. Over time, the students started to recognize new forms of learning that aligned with the bilingual teacher education program and new resources, such as relationships with peers, became part of the evolving ecology.

\section{Forming New Ecologies}

The reflective texts of the students illustrate the value of observing and critically considering the conditions of the new learning environment in order for them to start reforming their agentic ways of being and understanding of themselves, and, in effect creating a new kind of learning ecology for themselves. As in the following example from "Laura", the supportive and evaluation-free environment created a space for the re-formation of her agency as a 
language learner that was willing to take on the challenge of the new environment and to recognize the resources afforded by the other students:

(10) I have realized that I can't really do anything to my starting level as an English user in this program, but what I can do is try to learn new as much as possible, by using English as much as possible. I'm really glad that our group spirit in JULIET is so good. We all kind of help and encourage each other, for example if I don't know a word when I'm speaking, I don't have any threshold to ask it from others. Also our teachers have succeeded to create a significant environment to learn, where there is no pressure or expectations of complete perfection at all. (Laura, $2^{\text {nd }}$ essay)

Although the environment was experienced as supportive for many participants and offering possibilities for a variety of forms of participation, the process of changing one's own agentive responses was not easy. New ways of participation were experienced as something that necessitated them to step out of their comfort zone to embrace new ways of learning and being creative, as Elisabeth says:

(11) Little by little I learned to step out of my comfort zone and now in the end of the year I already feel like I have learned to enjoy being creative and learning ... I think this has encouraged us to ... use English without worrying too much ... (Elisabeth, $2^{\text {nd }}$ essay)

In addition to the supportive atmosphere, some learning methods were also experienced as central for the new ways of participating. Marie mentions what was of value to her in her comment:

(12) Indeed, we have used English in different contexts: plays, poems, pronunciation workshop, art etc. I in particular was inspired by the play An Inspector Calls which we acted at the end of the JULIET course. It was easy to throw myself into the play, since I have always been into acting. Through the play I felt I could reach something familiar, enjoyable which connect to myself. (Marie, $2^{\text {nd }}$ essay)

The students' reflections indicate that although the disjuncture between the use of English and their former beliefs had been an obstacle, over time using English to express themselves and experiencing the new environment became enjoyable and meaningful. The experience of using language to interact in a friendly atmosphere was new to many of the students in an educational context. At the end of the year, the students also started to recognize the new ways of learning a language as valuable ones:

(13) In reality, I have learned new mindsets, ways of thinking and become aware of many new things. Last week I went through all the papers from last year: actually we have done a lot of things. It has not felt that much because I have enjoyed every second of it. Moreover, I have not realized that I have learned a lot of English along the way. (Hannah, $2^{\text {nd }}$ essay)

For Hannah and many of the other students, using English to communicate and participate was a powerful resource for challenging previous ideas of language learning. Learning English along the way was something that they needed to get used to. The retrospective reflections of the students indicate that once they were able to acknowledge the disjuncture between what had been and what now was, the process of realigning agency and reforming their learner identities could take place.

\section{The/A Bilingual Learning Environment as a Resource for Future Language Teacher Identities}

The student essays indicate that towards the end of the program the students recognized that their ideas of language, their own identities and language teaching had changed. The experiences of this new language education ecology enabled new ways of understanding language and their relationship to language as learners and future teachers. In their reflective essays, Marie and Annie pondered the meaning of language for their identities:

(14) Nowadays English presents itself in my eyes as a symbol of globalization and my main motivation of learning the language is a need of self-expression and self-development. (Marie, $3^{\text {rd }}$ essay)

(15) I dare to say that without English being the global language, I would not be the same person who I am today... I have built my identity through English as well as through Finnish. The way I pronounce 
words changes depending on the group I am with. ... I no longer feel inferior to native speakers. I am proud to be pronouncing with a mixed accent because it makes me who I am. I feel like a citizen of the World and I can only thank the English language for that. (Annie, $3^{\text {rd }}$ essay)

For most of the students, participation in an Englishmediated community was a way of transforming and enlarging their language identities. The agentive participation in this community seemed to give the participants an empowered feeling of being not only language learners, but also as part of the English language community. The experience of this reformed ecology of language learning and language use was also drawn on by the students to inform their future practice as teachers. Although still at the beginning of their teacher education, the students made connections between their experiences and their future roles as educators, as the examples from Elisabeth and Annie illustrate:

(16) During this year I have understood better that learning English is so much more than just learning things by heart and that thought has also shaped my idea of what kind of English teacher I would want to be. (Elisabeth, $1^{\text {st }}$ essay)

(17) The JULIET studies have partially been also selfreflective. I have questioned the language teaching methods my own teachers have used and what I have learned here has made me think whether learning could be done differently. (Annie, $2^{\text {nd }}$ essay)

In these examples, the students drew on the experiential resources of the past as well as the resources of the present environment in teacher education in light of the imagined future. For the students, the disjuncture between what they had experienced before and what they experienced in the program created the possibility of alternative models for future language learning ecologies. Questioning their teachers' ways of teaching was strongly connected to their own experiences. Towards the end of the research period, the students also explicitly pointed out their own experiential background as a resource for their work as teachers, as Marie explains:

(18) Being non-native speaker gives me asset to look English in different point of view: what are the basic difficulties for children, ... Being a multilingual is important because I have experience of learning English and empathy with my students' struggles. (Marie, $3^{\text {rd }}$ essay)

The experience of entering this CLIL-based teacher education program was a demanding experience for many of the students. As the ecology of the program continued to evolve, however, the struggles the students faced when trying to figure out new ways of participation were later experienced as resources that enabled a different kind of vision of themselves as future language educators, as well as of the wider ecology of language education.

\section{DISCUSSION}

In this article, we have illustrated the ways in which the identity and agency of future language teachers develop through participation in a CLIL-based teacher education program. In this program, most of the basic educational courses were studied through English in addition to the language pedagogy courses of JULIET. According to the student essays, entry into the program was often experienced as demanding and out-of-sync with their expectations. The experienced disjuncture was between beliefs of language learning as requiring grammatical correctness and fluency for participation and the notion that features of language develop along the way. Within these conditions, the participants' habitual agency was questioned. This new environment, however, also afforded new participatory practices through the example of older students as well as the evaluation-free and supportive emotional atmosphere. As the students became familiar with the new environment, the participants were able to use these resources to adopt new ways of being agentive and perceived a change in themselves as they began to use English more creatively and freely without the fear of mistakes. As the students renegotiated and realigned their relationship with this environment, a new language learning ecology was formed (van Lier, 2010). This ecology was shaped by the experiences, expectations and participation of the individuals as they responded to the expectations, requirements and resources of the new environment. Within this new ecological setting, the participants' perceptions of language learning and their visions of language teaching in the future also began to take shape. 
In the light of these illustrated experiences, it seems that the experience of a CLIL-based teacher education program can significantly inform students' development of agency and identity. Firstly, we would like to highlight the ways in which identity and agency are intertwined in the student teachers' development. Although other studies have indirectly addressed this relationship (e.g., Barcelos, 2016; Kalaja, 2016; Trent, 2013) describing identity development as an agentic process, few studies examine the nature of this relationship (e.g., Kayi-Aydar, 2015). When entering the teacher education program, the student teachers sought to make sense of the environment with the help of their previously formed identities - this is who I am, and their habitual agency - this is how I am. In the new environment, these established identities and agencies did not readily support their participation. The ways in which they assumed they should act - be willing to memorize, to be corrected, to strive to be native-like whilst defining themselves as nonnative, were neither affirmed nor valued as they had previously experienced. In response, the students began to question their previous identities as well as the new environment, and to look for forms of participation that aligned with who they wanted to be within this new environment: who they could be and how they could be. For the participants, this active process incorporated both carefully observing their environment and re-viewing their previous identities and agentic responses. Step-by-step the students experimented with, adopted and adapted new ways of using English with each other and in their studies. Through these experiences, the habitual agency of the students was re-formed and became a resource to inform the students' developing identity (Ruohotie-Lyhty \& Moate, 2015).

Secondly, we suggest that it was the profoundly personal experience of disjuncture enabled the student teachers to actively reflect on their experiences (cf. also Trent, 2013). An ecological perspective suggests that the disjuncture was so keenly felt by the participants because they were already actively expecting a different kind of environment (Holquist, 1983) and a "risky moment" began to take shape (Sade, 2009). As they noticed the loss of synchrony between their expectations and current experience, they began to question who and how they should now be and compare that with who they had been. It is this questioning, re-viewing and forming a response that is at the heart of reflective practice. Although teacher education programs commonly rely on reflection of previous experiences to support identity development (e.g., Freese, 2006), it is important to realize that any significant change in identity is realized through agentic action, just as agency is reciprocally informed by identity. By providing the conditions for reflection as well as for new forms of agency (Lipponen \& Kumpulainen, 2011), the student teachers had a range of experiential resources to draw on to develop their identities, which in turn nourished their agentic possibilities. Experiencing disjuncture within a new environment seems to draw attention to established habits and create a genuine need to reconsider what has been and what could be and the opportunity to critically consider what is educationally worthwhile for themselves as learners as well as future teachers.

Thirdly, we would like to highlight the constant interplay between the environment and the individual(s) in forming the ecology of learning. In our study, student development was an individual process as each individual actively observed their environment through their own experiences and beliefs whilst seeking ways to respond and reflect on their former and current responses. Recognizing the significance of the individual, however, should not downplay the social nature of development and the important role of the environment as students experienced and experimented with new roles. As the students stepped out of their established comfort zones, the support of the environment resourced their courage to act and provided material to reflect on. Through the individual actions and initiatives of participants, new affordances became resources for other participants to draw on (Biesta \& Burbules, 2003) going beyond the institutional resources of teacher education (Moate \& Ruohotie-Lyhty, 2014) as well as former habits (Levine, 2015). As the different participants responded to each other, to language education, as well as the study of education and reflected on who they had been, could be and wanted to be, so the ecology took shape simultaneously informing the identity and agency development of the participants. It is these different, yet interwoven relationships that inform the complex ecology of this CLIL-based teacher education program.

To us, these dimensions of the development process illustrate the complex nature of human development and the intertwined roles of identity and agency in forming an ecology for learning with its concomitant affordances and challenges (van Lier, 2010). This ecology could not be 
formed before the individual students entered into the environment and began to realign their outward orientation to the environment and their inward orientation to themselves. Nevertheless, this ecology drew on the individual and then shared pasts of the participants, as well as imagined futures as they took shape within the present (Pavlenko \& Lantolf, 2000). It is perhaps worth asking whether the personal nature of this negotiation and realignment suggests that multiple ecologies were actually created through this process or at least multiple experiences within a shared ecology. We acknowledge that the student teachers did not realign their relationships with the environment in the same ways. Different past histories provide different kinds of resources for present reconsiderations and future visions. Nevertheless, negotiations within a shared space create a complex web of relationships between and within each individual in relation to the environment. For us, this underlines the complexity, rather than multiplicity, of the ecology that encompasses participants as they enter into the process of language identity development.

Whilst complexity theorists might suggest that the emergent qualities or conditions of this ecology would be impossible to anticipate or stabilize (Larsen-Freeman, 2019), we would suggest that the formation of new habitual agency and developing identities do contribute to a stabilizing or centripetal dynamic (Bakhtin, 1981). Whilst significant, especially unexpected, events will introduce new disjunctures and possibly create a sense of chaos, from an ecological perspective earlier forms of agency and identities can be resourcefully drawn on to progress through risky moments, in effect providing continuity between what was and what now is. Through experience, new forms of agency and identity form and begin to habitualize and become established features of this new ecology: an ecology that takes shape and continues to form (Rayner, 2011; van Lier, 2010). Moreover, the formation of this ecology at least in part emerges through the reflexivity and responsivity of the participants to one another, as Larsen-Freeman (2019) also acknowledges. This suggests that human participants are not merely part of an ecology but "who" and "how" the participants are has profound implications for the formation of the ecology.

\section{CONCLUSION}

In conclusion, we can say that, in this context, the highly idiosyncratic experience of student teacher identity and agency development is resourced in significant ways by and within the surrounding environment. On the basis of this study, we would suggest that it is important for CLIL teacher educators to recognize the highly personal nature of this experience, but to also be aware that the surrounding environment, including the use and role of language as well as past experiences and developing relationships, significantly influence the developmental process. Although it is not possible - or even desirable - to form the ecology of language learning and development apart from the participants, it is important to be sensitive to the risk that learners have to take to enter into identity development, the challenge of asking questions, doubting beliefs and capacities, the fear of inadequacy and discomfort of feeling "out-of-place". Guiding and positively benefiting from this experience requires time and patience as students begin to renegotiate their identity and agency with and within the new environment, forming the new ecology for development. Hopefully this small-scale study illustrates the value of seeking a better understanding of the interplay between agency and identity in student teacher development and provides a useful theoretical conceptualization that can be used to further examine the development of language education ecologies, particularly the identity and agency development of future language educators.

\section{Notes on the authors}

Dr. Josephine Moate is a Senior Lecturer at the Department of Teacher Education at the University of Jyväskylä, Finland. Her research interests include teacher development as well as the role of language, culture and pedagogical innovation in and across education.

Dr. Maria Ruohotie-Lyhty is a Senior Lecturer in applied linguistics at the Department of Language and Communication Studies at the University of Jyväskylä, Finland. Her research is broadly situated in the area of identity, agency and emotions in language learning and teaching. 


\section{REFERENCES}

Aro, M. (2016). In action and inaction: English learners authoring their agency. In P. Kalaja, A. M. Barcelos, M. Aro, \& M. Ruohotie-Lyhty (Eds.), Beliefs, agency and identity in foreign language learning and teaching (pp. 48-65). Palgrave Macmillan. https://doi.org/10.1057/9781137425959 4

Bakhtin, M. M. (1981). The dialogic imagination: Four essays by M. M. Bakhtin. University of Texas Press.

Bakhtin, M. M. (1993). Toward a philosophy of the act. University of Texas Press.

Barcelos, A. (2016). Student teachers' beliefs and motivation, and the shaping of their professional identities. In P. Kalaja, A. M. Barcelos, M. Aro, \& M. Ruohotie-Lyhty (Eds.), Beliefs, agency and identity in foreign language learning and teaching (pp. 71-98). Palgrave Macmillan. https://doi.org/10.1057/9781137425959_5

Barkhuizen, G. (2009). An extended positioning analysis of a pre-service teacher's better life small story. Applied linguistics, 31(2), 282-300. https://doi.org/10.1093/applin/amp027

Bauman, Z. (2000). Liquid modernity. Polity Press. https://doi.org/10.5565/rev/athenead/v1n0

Biesta, G., \& Burbules, N. C. (2003). Pragmatism and educational research. Rowman and Littlefield.

Block, D. (2007). The rise of identity in SLA research, post Firth and Wagner (1997). The Modern Language Journal, 91(S1), 863-876. https://doi.org/10.1111/j.1540-4781.2007.00674.x

Bruner, J. (2012). What psychology should study. International Journal of Educational Psychology, 1(1), 5-13. http://dx.doi.org/10.4471/ijep.2012.01.

Coyle, D. (2008). CLIL—A pedagogical approach from the European perspective. In N. Van DeusenScholl, \& N. H. Hornberger (Eds.), Encyclopedia of language and education (pp. 97-111). https://doi.org/10.1007/978-0-387-30424-3_92
Dalton-Puffer, C., Llinares, A., Lorenzo, F., \& Nikula, T. (2014). "You can stand under my umbrella": Immersion, CLIL and bilingual education. A response to Cenoz, Genesee \& Gorter (2013). Applied Linguistics, 35(2), 213-218. https://doi.org/10.1093/applin/amu010

Duff, P. A. (2012). Identity, agency, and second language acquisition. In S. Gass \& A. Mackey (Eds.), The Routledge handbook of second language acquisition (pp. 428-444). Routledge. https://doi.org/10.4324/9780203808184.ch25

Dörnyei, Z. (2009). The L2 motivational self system. In Z. Dörnyei \& E. Ushioda (Eds.), Motivation, language identity and the L2 self (pp. 9-11). Multilingual Matters. https://doi.org/10.21832/9781847691293-003

Feryok, A. (2012). Activity theory and language teacher agency. The Modern Language Journal, 96(1), 95-107. https://doi.org/10.1111/j.15404781.2012.01279.x.

Freese, A. R. (2006). Reframing one's teaching: Discovering our teacher selves through reflection and inquiry. Teaching and Teacher Education, 22(1), 100-119. https://doi.org/10.1016/j.tate.2005.07.003

Giddens, A. (1984). The constitution of society. University of California Press.

Giddens, A. (2002). Modernidade e identidade. Jorge Zahar.

Holquist, M. (1983). Answering as authoring: Mikhail Bakhtin's trans-linguistics. Critical Inquiry, 10(2), 307-319. https://doi.org/10.1086/448248

Kalaja, P. (2016). 'Dreaming is believing': the teaching of foreign languages as envisioned by student teachers. In P. Kalaja, A. M. Barcelos, M. Aro, \& M. Ruohotie-Lyhty (Eds.), Beliefs, agency and identity in foreign language learning and teaching (pp. 124-146). Palgrave Macmillan. https://doi.org/10.1057/9781137425959_7

Kalaja, P., Barcelos, A. M., Aro, M., \& Ruohotie-Lyhty, M. (2016). Beliefs, agency and identity in foreign 
language learning and teaching. Palgrave. https://doi.org/10.1057/9781137425959

Kayi-Aydar, H. (2015). Teacher agency, positioning, and English language learners: Voices of pre-service classroom teachers. Teaching and Teacher Education, 45, 94-103.

https://doi.org/10.1016/j.tate.2014.09.009

Kramsch, C. J. (2009). The multilingual subject: What foreign language learners say about their experience and why it matters. Oxford University Press.

Kraftl, P. (2013). Geographies of alternative education: Diverse learning spaces for children and young people. Policy Press.

https://doi.org/10.1332/policypress/978144730049 $\underline{6.001 .0001}$

Lantolf, J. P., \& Thorne, S. L. (2006). Sociocultural theory and the genesis of second language development. Oxford University Press. https://doi.org/10.1093/applin/amm027

Larsen-Freeman, D. (2019). On language learner agency: A complex dynamic systems theory perspective. The Modern Language Journal, 103, 61-79. https://doi.org/10.1111/modl.12536

Larsen-Freeman, D. (2007). On the complementarity of chaos/complexity theory and dynamic systems theory in understanding the second language acquisition process. Bilingualism: Language and Cognition, 10(1), 35-37. https://doi.org/10.1017/s136672890600277x

Levine, S. (2015). Hegel, Dewey, and habits. British Journal for the History of Philosophy, 23(4), 632656.

https://doi.org/10.1080/09608788.2015.1031634

Lipponen, L., \& Kumpulainen, K. (2011). Acting as accountable authors: Creating interactional spaces for agency work in teacher education. Teaching and Teacher Education, 27(5), 812-819. https://doi.org/10.1016/j.tate.2011.01.001

Mercer, S. (2012). The complexity of learner agency. Apples - Journal of Applied Language Studies,
6(2), 41-59. http://urn.fi/URN:NBN:fi:jyu201302041153

Meyer, O. (2010). Introducing the CLIL-pyramid: Key strategies and principles for quality CLIL planning and teaching. In M. Eisenmann \& T. Summer (Eds.), Basic issues in EFL-Teaching and Learning (pp. 11-29). Universitätsverlag Winter GmbH Heidelberg.

Miller, E. R. (2016). The ideology of learner agency and the neoliberal self. International Journal of Applied Linguistics, 26(3), 348-365. https://doi.org/10.1111/ijal.12129

Moate, J. (2011). The impact of foreign-language mediated teaching on teachers' sense of professional integrity. European Journal of Teacher Education, 34(3), 333-346. https://doi.org/10.1080/02619768.2011.585023

Moate, J. (2013). Reconceptualising teacherhood through the lens of foreign-language mediation. Jyväskylä, Finland: University of Jyväskylä. Jyväskylä studies in education, psychology and social research, 459. http://urn.fi/URN:ISBN:978-95139-5034-7

Moate, J. (2014). Dialogic struggles and pedagogic innovation. Pedagogy, Culture \& Society, 22(2), 295-314. https://doi.org/10.1080/14681366.2014.891641

Moate, J., \& Ruohoti-Lyhty, M. (2014). Identity, agency and community: reconsidering the pedagogic responsibilities of teacher education. British Journal of Educational Studies, 62(3), 249-264. https://doi.org/10.1080/00071005.2014.955456

Moate, J., \& Ruohotie-Lyhty, M. (2020). The emotional journey of being and becoming bilingual. International Journal of Bilingual Education and Bilingualism, 23(2), 213-226. https://doi.org/10.1080/13670050.2017.1348464

Norton, B. (2006). Identity: Second language. In K. Brown (Ed.), Encyclopedia of language and linguistics (pp. 502-508). Elsevier. https://doi.org/10.1016/b0-08-044854-2/00624-6 
Norton, B. (2013). Identity and language learning: Extending the conversation. Multilingual Matters. https://doi.org/10.21832/9781783090563

Norton, B. (2016). Identity and language learning: Back to the future. TESOL Quarterly, 50(2), 475-479. https://doi.org/10.1002/tesq.293

Owens, D. (2017). Habitual agency. Philosophical Explorations, 20(2), 93-108. https://doi.org/10.1080/13869795.2017.1356358

Pappa, S., Moate, J., Ruohotie-Lyhty, M., \& Eteläpelto, A. (2017a). Teacher agency within the Finnish CLIL context: Tensions and resources. International Journal of Bilingual Education and Bilingualism, 65, 61-70.

https://doi.org/10.1080/13670050.2017.1286292

Pappa, S., Moate, J., Ruohotie-Lyhty, M., \& Eteläpelto, A. (2017b). Teachers' pedagogical and relational identity negotiation in the Finnish CLIL context. Teaching and Teacher Education, 65, 61-70. https://doi.org/10.1016/j.tate.2017.03.008

Pavlenko, A., \& Lantolf, J. P. (2000). Second language learning as participation and the (re) construction of selves. In J. P. Lantolf (Ed.), Sociocultural theory and second language learning (pp. 155177). Oxford University Press.

Rayner, A. D. (2011). Space cannot be cut—why selfidentity naturally includes neighbourhood. Integrative Psychological and Behavioral Science, 45(2), 161-184. https://doi.org/10.1007/s12124011-9154-y.

Ruohotie-Lyhty, M. (2013). Struggling for a professional identity: Two newly qualified language teachers' identity narratives during the first years at work. Teaching and Teacher Education, 30, 120-129. https://doi.org/10.1016/j.tate.2012.11.002

Ruohotie-Lyhty, M., \& Moate, J. (2015). Proactive and reactive dimensions of life-course agency: mapping student teachers' language learning experiences. Language and Education, 29(1), 4661. https://doi.org/10.1080/09500782.2014.927884

Ruohotie-Lyhty, M., \& Moate, J. (2016). Who and how? Preservice teachers as active agents developing professional identities. Teaching and Teacher Education, 55, 318-327. https://doi.org/10.1016/j.tate.2016.01.022

Sade, L. A. (2009). Complexity and identity reconstruction in second language acquisition. Revista Brasileira de Linguística Aplicada, 9(2), 515-537. https://doi.org/10.1590/S1984$\underline{63982009000200008}$

Sullivan, P. (2012). Qualitative data analysis using a dialogical approach. SAGE.

Sylvén, L. K. (2013). CLIL in Sweden-why does it not work? A metaperspective on CLIL across contexts in Europe. International Journal of Bilingual Education and Bilingualism, 16(3), 301-320. https://doi.org/10.1080/13670050.2013.777387

Trent, J. (2013). From learner to teacher: Practice, language, and identity in a teaching practicum. Asia-Pacific Journal of Teacher Education, 41(4), 426-440. https://doi.org/10.1080/1359866X.2013.838621

Vanderstraeten, R., \& Biesta, G. (2006). How is education possible? Pragmatism, communication and the social organisation of education. British Journal of Educational Studies, 54(2), 160-174. https://doi.org/10.1111/j.1467-8527.2006.00338.x

van Lier, L. (2008). Agency in the classroom. In J. P. Lantolf, \& M. E. Poehner (Eds.), Sociocultural theory and the teaching of second languages (pp. 163-186). Equinox.

van Lier, L. (2010). Foreword: Agency, self and identity in language learning. In B. O’Rourke \& L. Carson (Eds.), Language learner autonomy: Policy, curriculum, classroom (pp. ix-xviii). Peter Lang.

Vitanova, G., Miller, E. R., Gao, X., \& Deters, P. (2014). Introduction to theorizing and analyzing agency in second language learning: Interdisciplinary approaches. In P. Deters, X. Gao, E. R. Miller, \& G. Vitanova (Eds.), Theorizing and analyzing agency in second language learning: Interdisciplinary approaches (pp. 1-13). Multilingual Matters. https://doi.org/10.21832/9781783092901 